Transmlsshon Electron Mlarescopy and Mobll lity of Iaterfacese Hesteresis and interond Eclat lon

R. Gotthardt, J. Stolber, Institut de Genle Atomique, Ecole polytechnlque Fédérale de Lausanne, CH-1015 Lausanne

\title{
Iatreduces 100
}

Martensitic transformations in non-ferrous alloys are generally accompanied by hysteresis effects. Hysteresis occurs when, during the martensitic transformation, energy is dissipated. It Indicates that energy which 13 needed to advance the forward transformation cannot be used for the reversed one. The reason for dissipating energy can be many-fold. As examples can be mentloned: nucleation processes, interaction of mlgrating Interfaces with the inicrostructure of the matrix (polnt-defects, precipitates etc.) and diffusion of polnt defects to interfaces after transformation. $A$ thermodynamic descrlption of how all these parameters influence the shape of the hysteresis curve is given by Delaey (1) while Hornborgen (2) discusses the effect of the transformation remperatures. Clearly, hysteresis effects allow the transformation behaviour to be modlfled through the control of microstructure by sultable thermo-mechanlcal treatments. This 13 particularly lmportant in cases where additlonal elements are added to alloys to get finer grains for better processing (3).

Conslderable effort has been made to understand the different observed hysteresis effects. Often, however, the given models can only explain the single system being studied and until now, no unlque extensive descrlption exists which is generally accepted. So the alm of this paper cannot be to review all the data on hysteresis effects. An overview of the studies on this topic is shown in recent conference proceedings (4).15). In this paper further information is glven which comes out of transmission electron microscopy observations of in-sltu transformation and from new results of internal friction measurements. They could contribute to reveal and understand mechanisms controling hysteresis effects.

\section{Experimental Techolaues}

Transmlsston Electron Mlarescoey (TEM)

TEM-observations have the great advantage that micro-mechanisms supposed to be responsable for macroscoplc properties can be studled directly. On the other hand, due to the often very hlgh magnification, the cholce of the part of the sample to be studied is very important in order to avoid the observation of artifacts. In addition, the samples have to be thin $(-0.1$ to $0.3 \mu \mathrm{m})$ in order to be transparent to electrons. Thls lact can change the microstructure of the observed part of the specimen and must be taken into account in the interpretation of results. 
The conventional TEM-technlque (CTEM) is often used to determine crystallographlc structure of the phases involved and to reveal crystallographic orlentations and relatlonshlps of interfaces. In addition it allows the determination of Burgers vectors of dislocations and displacement vectors of stacking faults. (For more detalls see TEM handbooks (6) .

High resolution electron microscopy (HREM) allows even distances of Interatomic scales to be revealed (columns of atoms) which has extended our knowledge of interface structures considerably. For such studies, extremely thin samples are necded, so the near surfaces (image forces) Influence even more the microstructures. Thus, internal stresses, responsable for many properties observed macroscopically, are decreased or even completely relaxed.

Both techniques are based on static observatlons. With the help of gonlometer specimen stages precise crystallographic relationships can be determined, but it is very difflcult to relate these observations to the transformation process liself.

With special specimen stages it is posslble to change the cemperature of the sample. to apply a stress or even both simultaneously. Generaliy such specimen stages allow only a tliting about one axis, whlch is not enough for exact crystallographic studies. The major advantage 1s, however, that the transformation can be observed directly, which is of particular importance for the study of the thermoelastic martensitic transformation. By this method, the migration of an Interface between a martensitic plate and the matr $1 x$, or, between different martensite plates can be followed during temperature, stress or combined temperature/stress varlations. There are two modes for stress varlations. Firstly. stress can be applied by a pneumatic system which guarantees a constant load without relaxation (7). Secondly, the specimen may be deformed effectively to a certain amount with a given straln value which is then followed by relaxation. The appropriate specimen holder has to be chosen for a particular problem.

Lorernal Eriction Measuremants

By this method microscoplc mechanisms can be dectected which consume energy during a perlodic movement. For instance, if a specimen is exited to oscillation and one observes the decay of the free oscillation, the amplitudes decrease slowly in the case of low Internal Erlction (I.F. or $Q^{-1}$ ) and wlll be attenuated rapldly when the I.F. Is high. So, materlals wlth high I.F. have hlgh damping capacity. When I.F. Is measured as a function of Erequency at constant temperature, then a maximum is observed at the eigenfrequency characteristic of the respective mechanism. Ihls measurement mode is not always applicable, because the oscillation frequency of the measurement system can often not be varied over a blg enough frequency domain. Thus, many Installations are working by varying the temperature at constant erequency. Thermal activated processes are then observed by maxima at characterlstic temperatures, whlch depend obviously on the erequency used. The temperatures related to a martensitic 
transformation should therefore not bo changed when varylng the measuring frequency. whereas the amount of $Q^{-1}$ can do so. More detalls about I.F. relatod to theso transformations are given elsewhere (8).(9).(20). Because of tho fact. that I.F. measurements reveal mechanlsms consumling energy, this method is particularly Interesting for Investigatlons of hysteresls effects related to the martensitlc transformation. As went loned before. detalls of the shape of the hysterests are related to the Interaction of the interface with the microstructure of the matrix. Even if there 18 no general agreement about the structure of the Interface, 1t can be regarded as an ensemble of linear defects (mlsflt or coherence dislocationo (11)) which can interact with polnt defects, impuritles, preclpltates, grown-in or transformation Induced dislocatlons, other Interfaces, etc. Each of these mechanlsms influences the Internal friction in a characteristlc way. In addition I.F. depends on the denslty of moblie dislocations inslde a martensitlc plate and is Indirectly sensltive to tho distrlbution of internal stresses.

In order to get the maximum of Information from the same sample before, during and after the transformation, a special Installation lor the measurement of I.F. has been constructed. It Is an inverted torsion pendulum, operating at about $1 \mathrm{~Hz}$. In addition to the I.F. It allows the simultaneous measurements of the frequency. the electrlcal reslstlvity and the rotatlonal component of the shape change. The lrequency glves useful Information on the shear modulus. The electrlcal resistance shows the amount of transformed materlal. For quantitative Interpretation it has to bo considered that the sample can change $1 t 3$ length and $1 t s$ sectlon [12]. whlch change the resistance, wlthout changling the speclflc resistivlty. The measured shape change can only be used qualltatlvely but le glves addlelonal Information on the characterlstic transletion terperatures. For this investlgation the pendulua was modilled In such a way. that a tenslle stress could be applled during the osclilation of the sample, whlch allows the study of transformatlons under stress, lmportant tor most applications.

\section{IEM Obseryar loas}

The presented results concern mainly observations of in-sleu transformation Induced by cemperature and/or stress varlations wlth special emphasis on migrating defocts which are able to consume energy. Crystallographic relat lonshlps are not given here, but are simliar to those observed under statlc conditions by other authors $(13),(14)$.

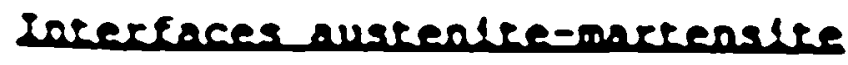

Two eypes of interface algration have to be considered.

a) the movement of the elp of a plate

b) the thlckenling process. 
The appearance and growth of a martensitlc plate has bech observed and analysed quantitatively in a Au-Cu-2n alloy (Ms - $180 \mathrm{~K}$ ). The plate appears suddenly and has immediately a certaln thickness, showing a very high velocity parallel to the hablt plane. In this situation the plate remalns a certain time before fumplng to a greater thlckness. When the tip can be followed this process is scen by a stop-and-go movement. After a certaln time, the thickening process becomes smooth (F1g. 1). The same behaviour is observed in $\mathrm{Cu}-\mathrm{Zn}-\mathrm{Al}$ martensitic alloys. An advancing $t$ ip of a martensitic plate Induces an elastlc stress fleld in the surrounding matrlx. which can be seen by TEM in thin foll. Due to stress relaxation, the background intensity changes around the $t$ ip [15]. Such tlps retract Immedlately when stress or temperature rates are inversed (16). Thermal cycling seems to increase the number of favorably orlented martensitlc plates in contrast to stress cycling $(17)$.

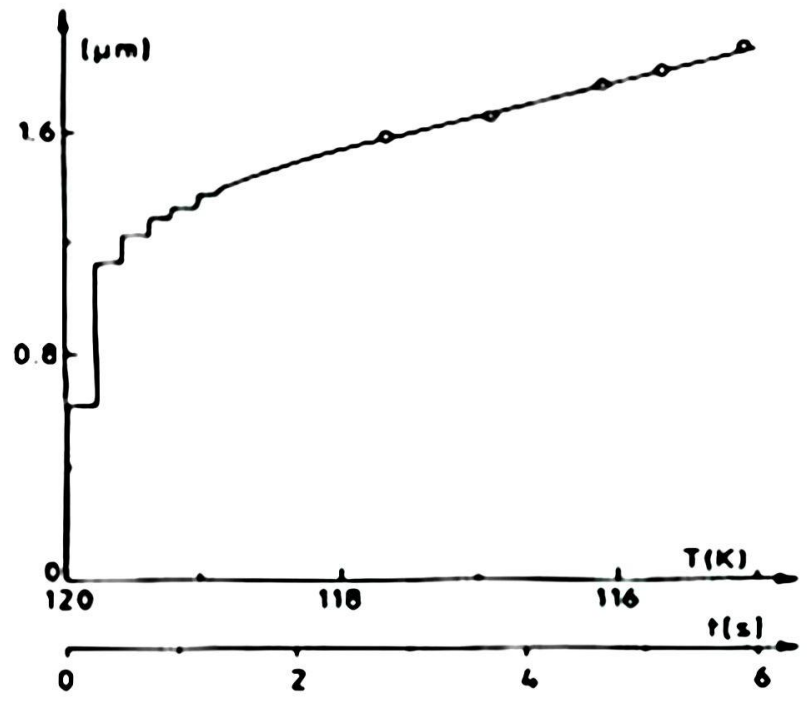

Flg. 1: Growth of a martensite plate

(thickening) in a Au-Cu-zn alloy; taken

from TEM-video recording of an in-situ

transformation.

Dislocation tangles, whether they are introduced during solldiflcation or by thermal cycling had no stopping effect on a moving interface.

Careful observations have been made in order to detect the starting polnt of the transformation. The dislocation tangles mentioned earlier are seen not to be the origin of the cransformation, at least not in thin parts even if the thermal cycling is carried out in an already thinned sample.

On the contrary, nucleation has been observed in parts where stress is acting, like at borders of holes or other stress concentrations seen by bend contours. This stress can, when favorably orlented, nucleate the new phase. This happened often, being not directly at the border but somewhere inslde the sample. 
Mostly, tho martensitic plates are growing from thick parts into the electron transparent ones.

Laterfaces martensite-martensite

As can be seen later from I.F. results, martensite-martensite Interfaces seem to play an Important role for the appearance of a hysteresls effect. So these interfaces have been studied too.

In-situ transformation has been carried out in a Jeol $200 \mathrm{Cx}$ microscope operating at $200 \mathrm{kV}$ in a Cu-2n-Al alloy (nominal composition 19.26 at. In and 14.37 at. Al). This composition was chosen in order to have a low Ms $(=160 \mathrm{~K})$ so the transformation can take place without beling perturbated by thermal diffusion of vacancies. The martensite was induced thermally as well as by deformation. In both cases the interface migratlons were accompanied by a change in the stacking fault arrangement. This can be detected by a change of the contrast of existing stacking faults and by moving limiting partial dislocations. Such an activity has already been observed in preliminary experiments (15).

In order to explain the obscrvations, a part of the specimen is presented schematically in Flg. 2. "I" indicates the position of the interface. Above and below two varlants are shown together with thelr stacking faults. Stacking faults able to move are labelled "p". When such a $P$ dislocation arrives at the interface, Its postetion is changed locally. Fig. 3 shows a 6 sec. section of the video $l 11 \mathrm{~m}$ recorded during heating of a martensitlc part of the specimen. The flim was stopped at the shown moments, the Images recorded by a videoprinter and then photographed in the shown arrangement. An lntensive stacking fault migration is observed without a long distance interface migration. Advancing stacking faults can be followed by their characteristic superimposed contrasts, slmplified graphics are added to find those contrasts.

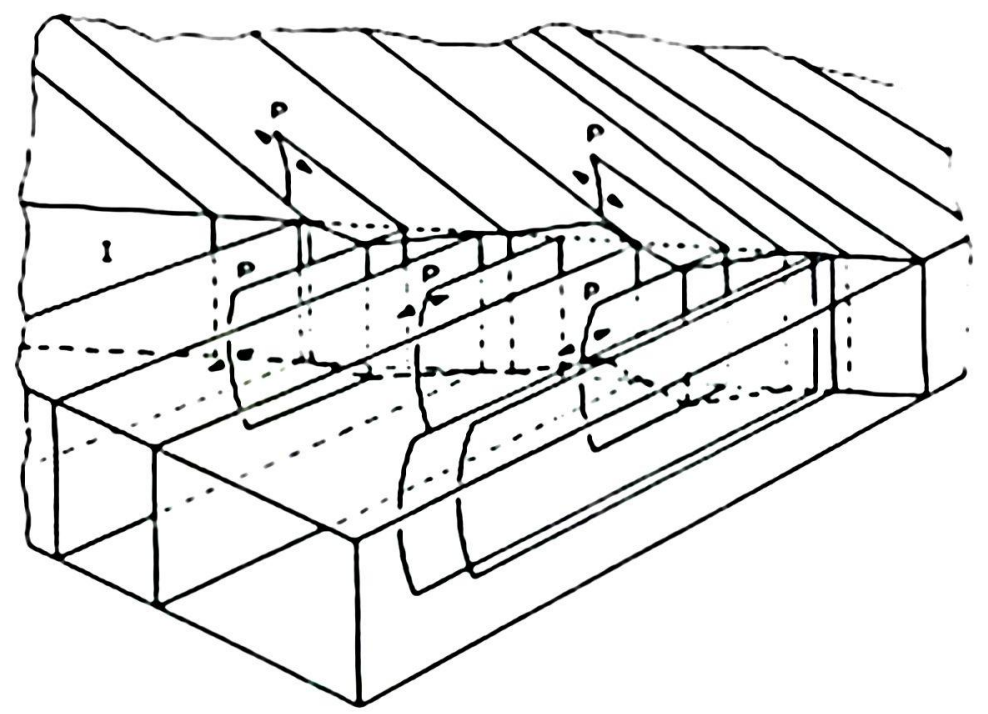

Fig.2: Schematic representation of a part of a TEM sample. I: plane of interfoce, P: moving partial dislocation limiting growing or shrinking stackling faults 

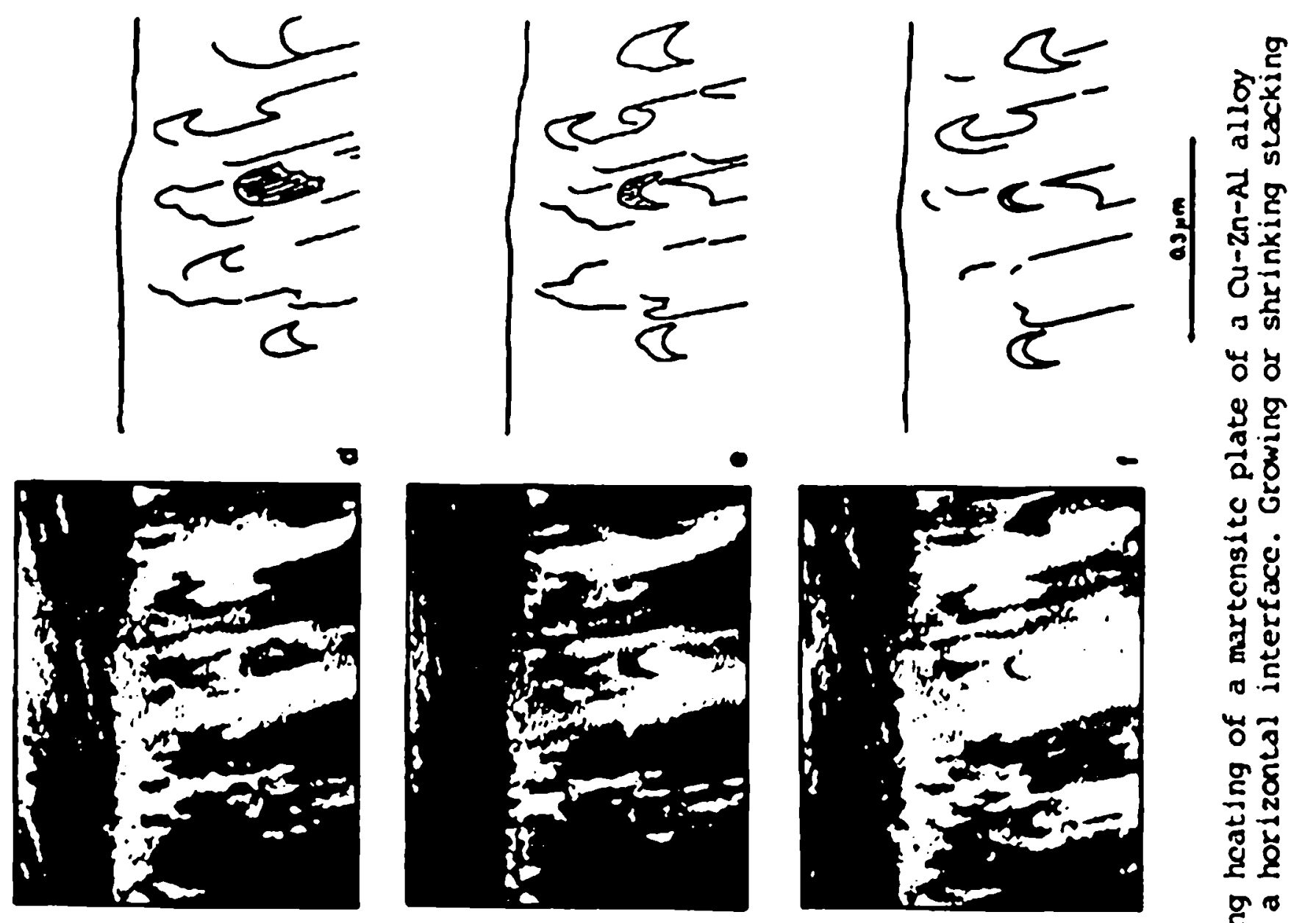

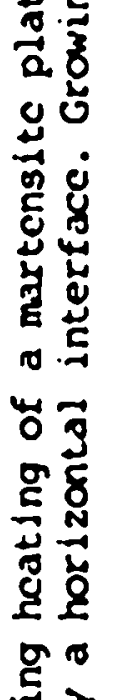
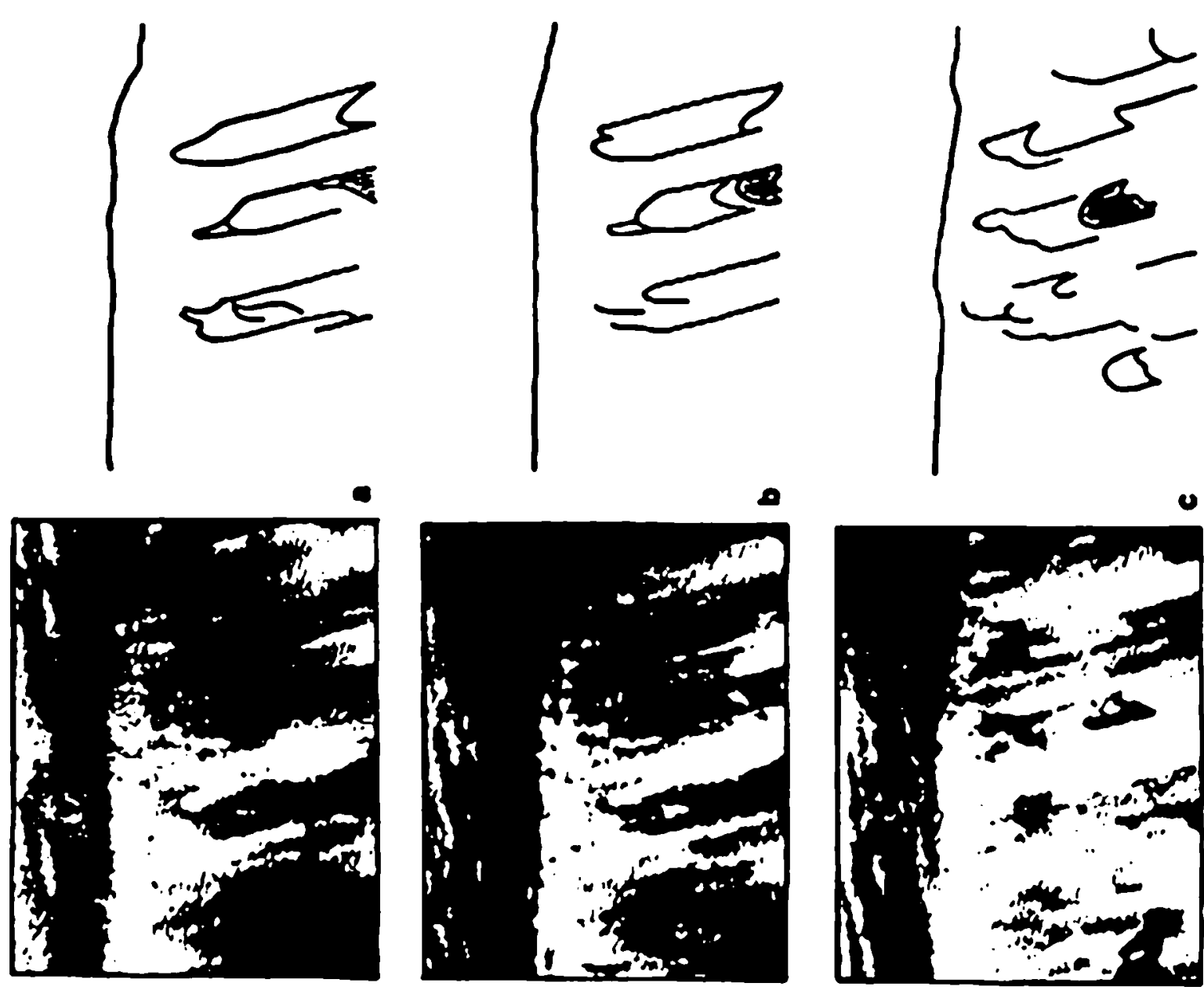

击

ริ

둥

항

웡

\&

8 है पे

क ल 8

๙

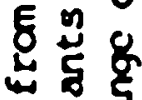

ธ ने है

㓱 9

บ
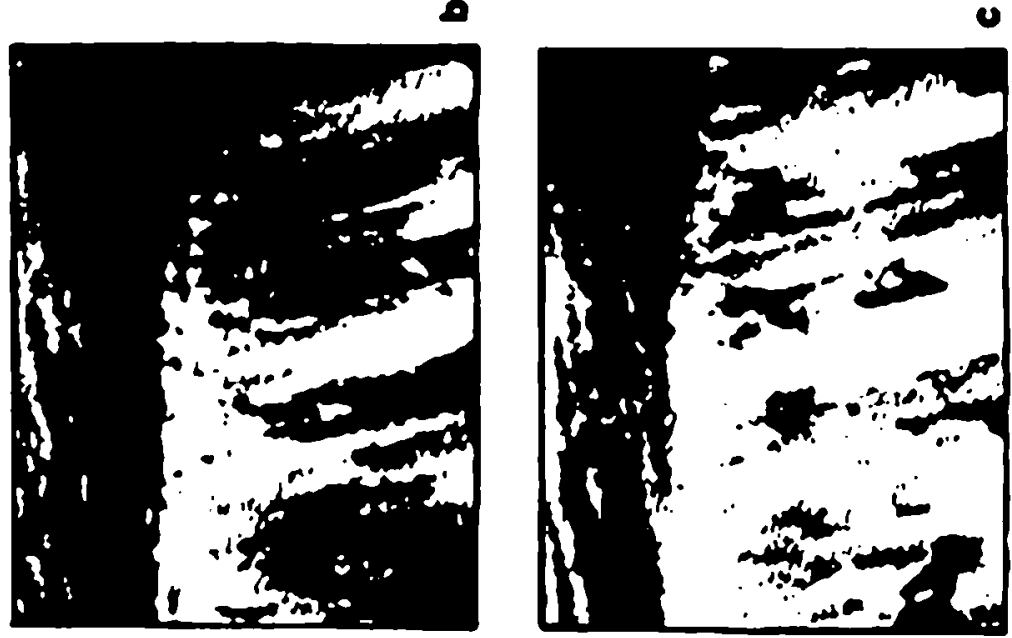

है ह

os

幽岕

है 8

ह 5

i.

羊究 


\section{rokernal Eclation}

All results are measured in alloys of nominal compositelon of Cu$2612 n$ - 141 Al whth a Ms of about $290 \mathrm{X}$ measured by calorfmetry.

r1g. I shows the evolution of $0^{-1}$ as a function of temperature. The wost important result is that the 1.F. at the boginning of the eronsformation does not depend on tho measuresent amplitude 2 . where in the alddie of the transformation dorain $0^{-1}$ is auch saaller for hlgher chthan for sall ones. Inslde tho rartensite

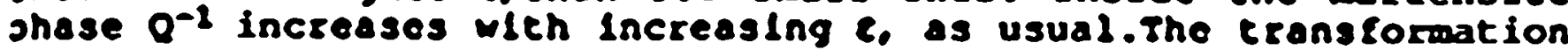
cemperatures seen by the reslstance measurements aro not changed oy varying the amplltude.

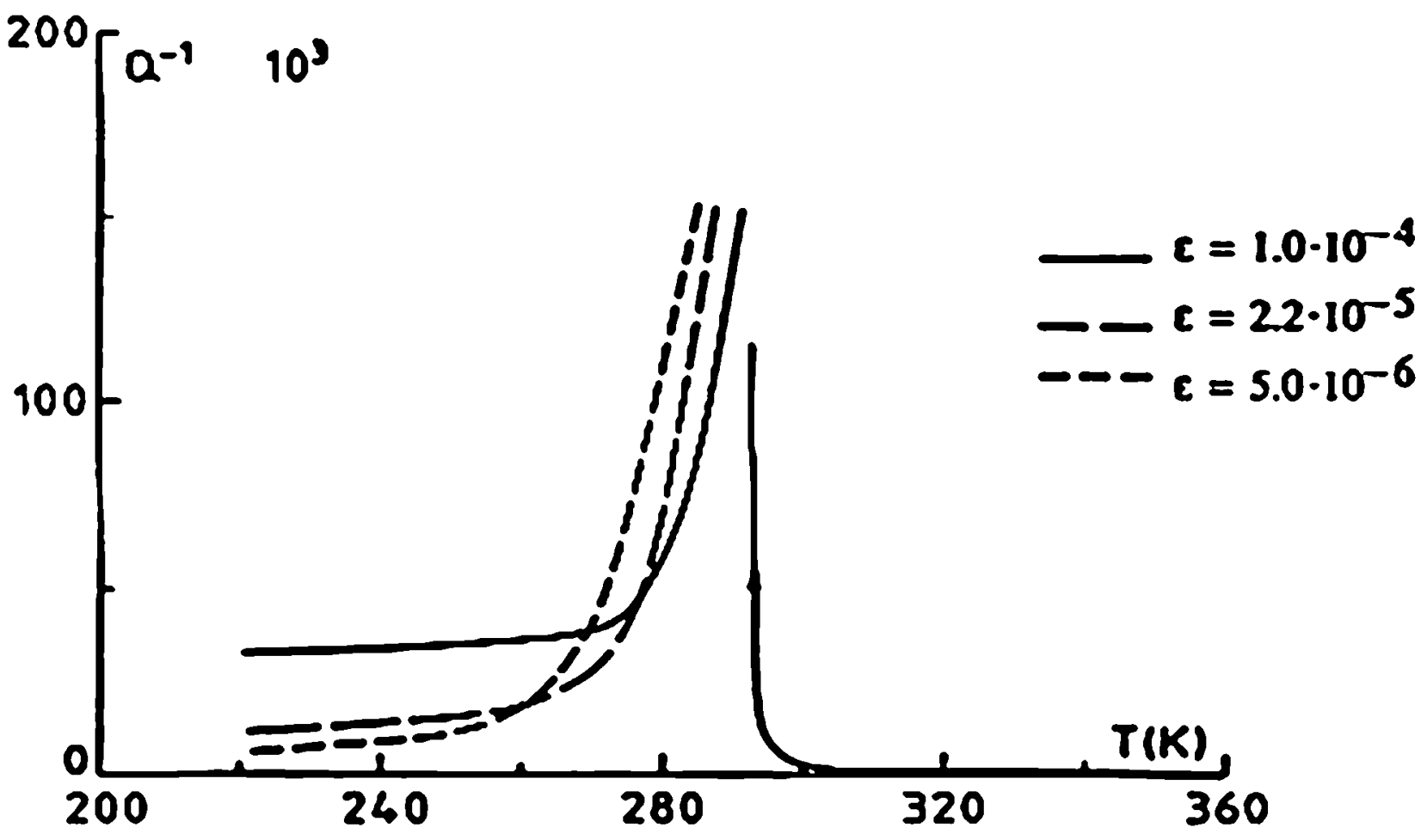

Fig.4: Intornal erletion (0-1) ovolution as a function of

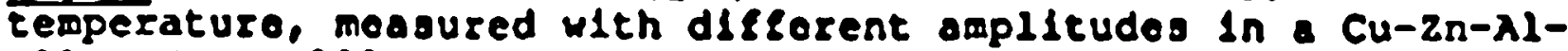
alloy (MS - $290 \mathrm{~K}$ )

If the temperaturo change is stopped every $5^{\circ}$, the $0^{-1}$ values drop drastically to lowor valies. Flg. S shows clearly for the case of coollng that the blggest contrlbutlon to $0^{-1}$ stems 8 rom transitory olfects, the torm depending on the temperaturo change rate t $-\mathrm{dT} / \mathrm{dt}$.

Tho $0^{-1}$ evolution 18 shown for an amplitude $e=2.2 \times 10^{-5}$. Changing c. one finds that the t-contrlbution durlng eransformation decreases with lncroasling evalues. Inls is shown in more detall - lscwhere $[17]$.

In order to study hysteresls elfects at sall scale, repperature cycles of $10 \mathrm{~K}$ wldeh have been performed at dlflerent temperature 


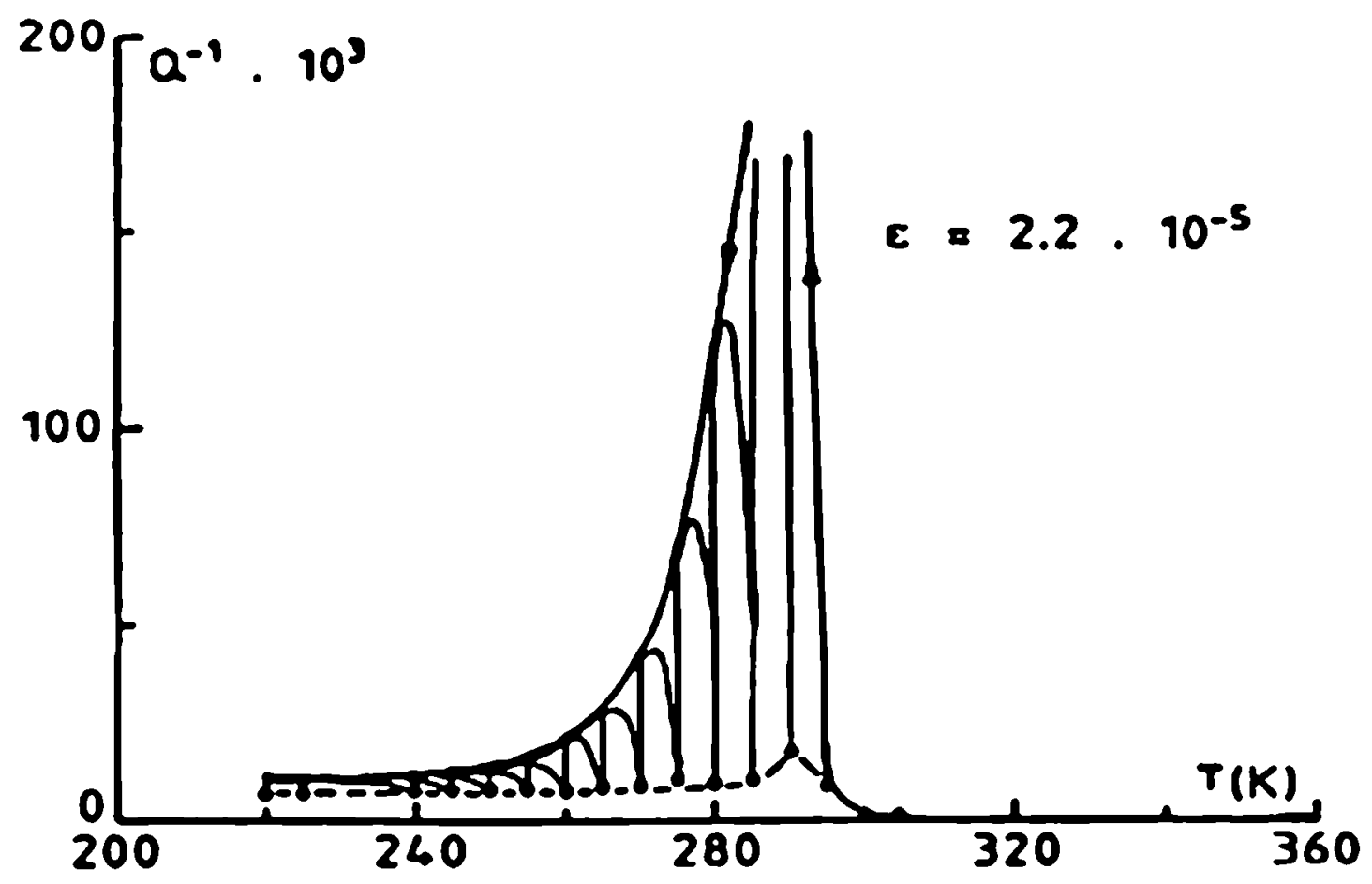

F19.5: $0^{-1}$ evoluelon as a luncelon of teaperature during cooling. The decreasing temperature has been beld constant every $5 \mathrm{~K}$.

Intervals. Tho rosults are shown In Flg. 6. Flg. 6a and 6b present the resulta of cycling in tho samo interval but otarting from martenste or erom austenlto rospoctlvely, whoroas in FIg. 6c cycling is performod around $A$. For the dlscussion of differences In resistance-terperature cycles measured in tho oame temperature reglo2 $(290 \mathrm{~K}$ - $300 \mathrm{~K})$ the correspondling reslatance curves whlch are at different reslstance levels are superlrposed in Fig. 7 .

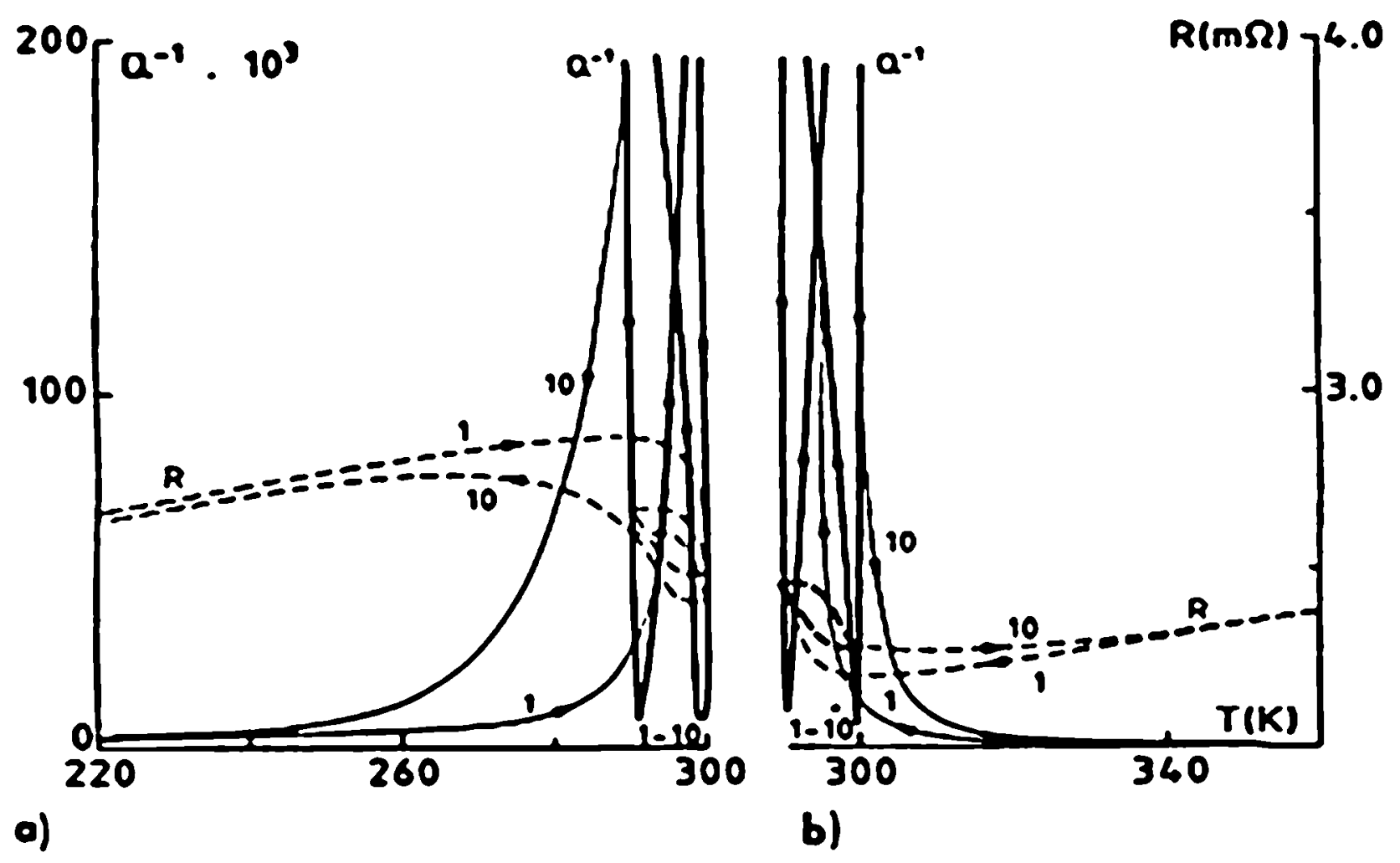




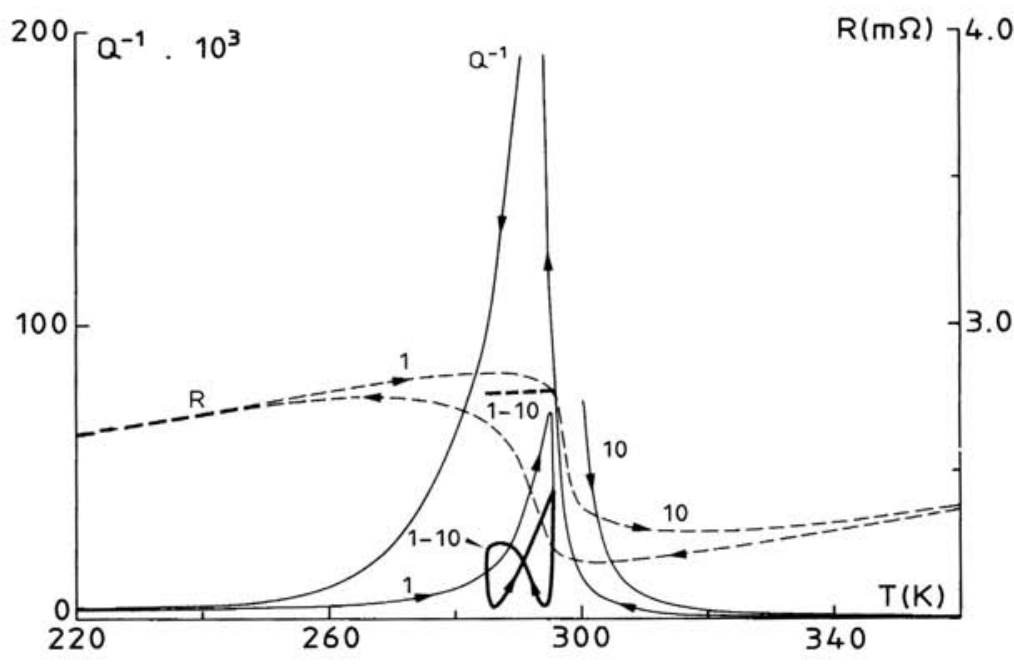

Fig.6: Small partial temperature cycles performed at

C) different temperature intervals, cycles between $290 \mathrm{~K}$ and $300 \mathrm{~K}$ (a) starting from martensite (b) same interval starting from austenite (c) cycling around As starting from martensite.

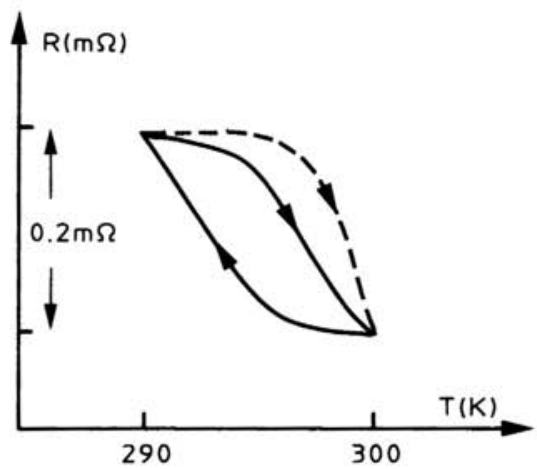

Fig.7: Electrical resistance as a function of temperature during partial cycling, taken from Fig. 6 a and $b$.

\section{Discussion}

The discussion will be concentrated on the interface migration. In the domain of the entire hysteresis, which is in general the transformation region, the high I.F. values are normally believed to come from migrating martensite-austenite interfaces [18]. 
Partial temperature cycles made at different parts of the hysteresis together with TEM observations of ln-situ transformation give interesting information on migrating defects.

The small cycles around As-temperature (FIg. 6c) show no evolution of the reslstance curves, they remain straight and do not decrease with the number of cycles. The $Q^{-1}$ values, however, change in such a way that a characterist1c "butterfly" shaped curve results. Due to the fact that resistance curves indicate changes in the transformed volume, thls result reveals other than transformation mechanlsms giving rlse to the gulte high I.F. variations. At each end of the cycle the slgn of $T$ is changed in the pendulum and $\dot{T}$ passes with a small phase shlft through zero at the sample resulting in smallest $Q^{-1}$ values, as also seen in the case of the entire $Q^{-1}$ curve presented in Fig. 5 .

The cycles made at higher terperatures. Fig. 6a and Fig. 6b should reveal effects of transformation because the resistance values change slgniflcantly. In both cases the cycling has been performed in the same temperature interval, so thermally activited processes, when present, should contribute in the same way. The total amount of martensite in the case of Fig. 6a is bigger than In the case shown in F19. 6b. The changes of the $Q^{-1}$ values are very strong. they are as big as they are observed during complete cycles. Nevertheless, as the reslstance curves indicate, only when starting from austenlte (Fig. 6b) material is transformed during the whole interval, during cooling as well as during heating.

On the contrary, when starting from the martensitic state, material is transformed only in the second half of the heating period (see also Fig. 7, dotted line). So again there should be another mechanlsa which induces high I.F.

The TEM observation of a martensitlc plate during heating reveals a very active stackling fault migration (F1g. 3). Stacklng faults arriving at the lnterface produce local changes in the internal stress fleld which alters the posltion of the interface, often accompanied by the emission of stacking faults in the adjacent nelghbour variant. Durling the whole sequence shown in Fig. 3 , the Interface has not moved remarkably. Such an activity creates a hlgh number of migrating defects and a highly locally moblle martensite-martensite interface, glving rise to high I.F. Whthout changing the transformed volume. So these mechanisms are probably responsible for the $Q^{-1}$ evaluation observed in Fig. $6 \mathrm{c}$ and in the flrst half of the heating interval of Fig. $6 a$.

The observations of migrating stacking faults during in-situ transformation are in contradiction to displacement vector determination under static observation conditions made by CTEM studies (29) or HREM studies (20), (21). They conclude that no shear type stacking faults are present in Cu-zn-Al (18R type) martensite, although moving stacking faults are observed frequently when interfaces move $(15)$. 
This discrepancy can be explained by the different conditions during the respectlve observations. In the static cases, especially in HREM studies, Internal stresses which appear necessarlly durling the transformation are relaxed. The shear type stacking laults which are evidently posslble during in-situ transformation when temperature and existing internal stresses change slmultaneously, convert before observation in the static cases. In other words, the lnternal stresses acting during the insltu transformation allow the observed shear type stacking faults which transform immedlately to non shear type ones when stress is relieved.

Glide processes parallel to basal planes are also proposed by Rlos-Jara (22) to explain the preferential presence of certain types of stacking fault displacement vectors.

zonsidering moving stacking faults, it is possible to discuss the I.F. and resistance measurements, made in the same cemperature interval (Fig. 6 a and b).

Coming from austenite, the reslstance decreases 1mmediately when reheating the specimen (F1g. 7, continuous line). This means, that there are still enough plates ending with tips at the end which are surrounded by elastic stress flelds. These tips retract when changling the sign of $\dot{T}$, thereby decreasing the transformed volume. In the case of transforming from martensite practically no single plates with tips at thelr ends are present. So when heating. first stacking lault rearrangement occurs as shown in Fig. 3 without changing the transformed volume (Flg. ?, dotted IIne). Then retransformation take place creating some free ending tips. These tips start growing lmmedlately when cooling again, explaining the superixposed cooling curves in both cases (Flg. 7 ).

The amplitude $\varepsilon$ dependence of the I.F. evolution during transformation (EIg. 4) is not yet understood, but can be related to the number of mlgrating stacking faults. The hlgher I.F. usually measured inslde the martensitic phase with hlgher values, can be explained by reorlentation of martensice-martensite Interfaces.

\section{conclustons}

- Internal friction measurements and TEM in-situ transformation observatlons have shown that, In order to explain hysteresis effects, not only martensite-austenite interfaces, but also martensite-martenslte interfaces have to be considered. Thelr mutual influence depends on the position inside the hysteresis (beginning, middle, end) and the phase distribution for which temperature and/or stress varlations are consldered. Martensitemartensite interfaces become locally highly moblie due to changes in stacking fault arrangements and thereby create high internal Eriction.

- The observed stacking

fault movement is probably only possible due to the slmultaneous action of temperature change and stress. 
Wlthout applled etress, st 111 atacklng fault wovemant 13 observed whlch akes evldent the laportant rolo of laternal atresses durlng warteaslelc eranstormation.

- Using relatlvoly puro alloys, the mlgration of martensltoaustentto interfaces 18 qulte smooth after tho carly stages of growth. Dlslocation tanglos seen not to be vlalblo obstacles to the mlgration of interfaces.

\section{Belerences}

(1) L. Delaey. J. Ort in and J. Van Humbeeck, in rol. (5).P.60.

(2) E. Hornbogen, Acta Het.. 33 (1985). S95.

(3) R. Elst, L. Delaey and J. Van Humeeck, in rel. (1).P.891.

(4) Proceedings of tho Intern. Cont. On Martensle lc Transformation. The Jap. Inst. of Motals (1986).

(3) Phase Transtormation'87, Ed. G.W. Lorlmer, The Inst. of Metals (2988).

(6) L. Releer. Transmlssion Electron Mlcroscopy. Springer Verlag (12984).

(7) R. Gotthardt, B. Gulsolan, Ph. Buffat, J. Mlcrosc. Spectrosc. Electron, 4 (1979) 587.

(8) J. Van Humbeck, in Proc. of the Sumer School on "Int. Erlcelon in Solids". Cracow, Poland, Ed. S. Corcryca, I.B. Magalas (1984), P. 131.

(9) W. Benole, G. Grexaud, R. Schaller, in oplastle Deformation of hoorphous and Seml-crystalline Marerlals, Ed. Escalg and G'Sell, Lea Editions de Physlque, (1982) 65.

(10) R. Gotthardt, in "Dlo martenslt locho Phasenumwandlung und deren workstofftechnische Anwondungen". Ed. E. Hornbogen, $M$. Thumann, DGM-Informatlonsgesellschalt Verlag (1986), P. 75.

(11) G.B. Olson and M. Cohen, hete Mez.. 27 (1979) 1907.

1221 C.H. Hsu, M.S. Hechsler, In -Solld-Solld Phaso Translormatlon". Ed. H.J. Maronson et al.. Tho Met. Soc. of AINE (1982), P. 1293.

(13) K. Adachl and J. Perklns, Met. Trans. A.. 16 A (1985). 1551.

(14) K. Adachl. J. Perklns and C.M. Hayman, in Rel. [4],P.838.

(15) R. Gotthardt, Discussion Meetling on Cu-zn-Al Martensite. Report R.84-1984, Dep. of Met. and Mat. Eng.. K.U. LEUVEN, Belglun.

(26) R. Gotthardt and O. Mercler. J. de Physigue, 12 (1981) CS995.

(17) J. Stolber, R. Gotthardt, J. Van Humbeeck, In thls Proceedlnga.

(18) J.F. Delormo, P.F. Gobln, Meraux No 573, (1973), 185

(19) M. Andrade. M. Chandrasekaran and 2. Delaey. Acta Met.. 32 (1984) 1809.

(20) F.C. Lovey, G. Van Tendeloo, J. Van Landuyt and S. Nmel Inckx, Scripta Mot.. 19 (1985) 1223.

(21) J.M. Cook, M.A. O'Koefa, D.J. Sintth and W.M. Stobbs, J. of Mlcroscopy, 129 (1983). 295.

(22) D. Rlos-Jara and G. Guenln, In Rel. (4), p. 757.

Acknovledaereat

The authors would like to thank $A$. Couret at Crrs Joulouse for hls collaboration in observing in-situ transformation at low temperaturo by TEM. 